\title{
Can the Yield Curve Predict Economic Growth Performance? Empirical Evidence from Nigeria
}

\author{
Victor Ugbem Oboh* Sikiru Abidemi Abdulsalam \\ Monetary Policy Department, Central Bank of Nigeria
}

\begin{abstract}
The paper investigates the capability of the yield curve to predict future economic activity in Nigeria, especially before, during and after the 2016/2017 economic recession. Using quarterly data on the index of industrial production (as a proxy for economic growth) and yield spread, we generated regression results for various data samples including the era of the global financial crisis- GFC (2007-2009); pre-economic recession in Nigeria (2010-2015) and economic recession / slow recovery (2016-2019). Though the model behaved differently before, during and after the 2016/2017 economic recession, general results indicated the substantial predictive power of the yield spread in providing a good forecast of the level of economic activity up to four quarters into the future. The paper therefore, strongly demonstrated the influence of yield spreads in predicting the future level of Nigeria's economic activity.
\end{abstract}

Keywords: Yield curve, economic growth, recession, forecast, Nigeria.

DOI: $10.7176 /$ RJFA/12-10-05

Publication date:May $31^{\text {st }} 2021$

\subsection{Introduction}

The yield curve which simply plots bond yield against its time to maturity has been adjudged by several researchers as a reliable predictor of economic performance. An upward sloping or positive yield curve indicates an increase in economic activity, inflation rate and short-term interest rates. Contrastingly, a downward or negatively sloping yield curve signals a future decrease in all these variables (Duarte et al, 2004; Hvozdenska, 2015). Popularly measured as the spread between the 10 - year bond and the 3 - month treasury bill, the yield curve has increasingly been used as a simple valuable forecasting tool. Researchers consider its simplicity over other complex macro econometric models as an advantage as predictions could be used to check the reliability of results generated by more sophisticated models.

Specifically, the information content of the yield curve in predicting real economic activity began to attract significant attention in the literature in the 1980s. Majority of the earlier studies concentrated on the US economy (See Estrella and Hardouvelis, 1991; Stock and Watson, 1989; Turnovsky, 1989) while others covered some major countries in Europe (Berk and Van Bergeijk, 2000; Estrella and Mishkin, 1997; Davis and Fagan, 1997). For instance, Estrella and Hardouvelis, (1991) showed that the yield curve could be employed to provide useful information on the probability of US economy to experience recession (Mohapi and Botha, 2013). Apart from the US, it has been shown that the yield curve could predict recession in other countries such as Germany, France, Italy and the United Kingdom (Estrella and Mishkin, 1995).

A good prediction of future economic activity provides useful information for policy managers and practitioners. Both fiscal and monetary authorities rely on forecasts to choose their monetary policy paths and budget preparation respectively (Bonser-Neal and Morley,1997). This is more important as failure to anticipate future economic activity especially recession could have damaging impact on any economy. Reliable forecasts also enable businesses in their production planning. In the event of an unanticipated economic slowdown, for instance, financial institutions risk the loss of funds due to low investment flows. This further impacts the labour market negatively as such periods are characterized by employee lay-offs, low tax revenue to government and widened budget deficit (Mohapi and Botha, 2013).

Though, forecast of real economic activity has proven to be useful for making policy decisions, not all forecasts are reliable. Some researchers have cast doubt on the quality of forecasts generated by macroeconomic models due to non-availability of timely and reliable data as well as the sophisticated nature of the forecasting models (Bonser-Neal and Morley, 1997). These sentiments have led to renewed interest in the use of financial variables such as yield curve as supplements to the use of macroeconomic models forecasting.

Using financial variables such as yield curve to forecast real economic activity is based on several advantages. First, the readily availability of yield curve data provide an advantage compared to other macroeconomic indicators such as inflation, output growth etc. Secondly, the data on yield curve are usually not provisional and therefore the results of its analysis require no revision. Thirdly, the availability of data on long term interest rate facilitates long term macroeconomic forecasting for long maturing bonds.

Although, several studies have established the usefulness of the yield spread in predicting real economic activity in the United States and other developed economies, evidence in developing economies especially Nigeria is limited. This paper is therefore aimed at investigating the ability of the yield spread to predict future economic 
activity in Nigeria especially before and during the 2016/2017 economic recession. Understanding the power of the yield curve in predicting future real economic activity in the Nigerian environment would provide useful information for facilitating evidence-based decision making by policy makers and the business community.

\subsection{Theoretical Underpinnings}

From a theoretical perspective, the relationship between the term spread and future real output could be positive or negative. Various explanations have been adduced for this phenomenon in the literature (Cuaresma et al, 2005). The first explanation is based on the "common factor" effect of current monetary policy stance on both the term spread and real economic activity. Tightening of monetary policy by a credible central bank raises short term interest rate while the effect on long term rates is minimal or non-existent, resulting in a flattened yield curve. Following a lag of few quarters, the tight monetary policy stance dampens output growth because of the fast pace at which the term spread reacts.

The second channel relates to market expectations about changes in future monetary policy stance. For example, an expected monetary policy tightening in the future would lead to an anticipated higher future short term rates, hence a rise in current long term rates eventually resulting in an increased term spread. This would lead to a slowdown in current and future real economic activity.

The third channel works through real demand shocks in which an anticipated economic upswing increases expected short term rates. Due to the rational expectation hypothesis of the term structure arbitrage condition, this anticipation results in higher current long-term rates.

The fourth channel explains the relationship between the term spread and future economic activity from an intertemporal consumption smoothing theory. Based on the consumption capital asset pricing model, linear relationships exist between expected returns and consumption growth. As a result, a co-movement between term structure and the business cycle is expected (Campbell, 1988).

Of all the channels discussed, the explanation based on the expectation hypothesis stands out. Essentially, the theory states that long-term interest rates are the average outcomes of expected future short-term interest rates (Haubrich and Dombrosky, 1996). The popularity of the expectation hypothesis draws from its ability to deal with both short term and long-term interest rates (Drakos, 2001). According to this hypothesis, the yield (at time t) is equal to an ' $\mathrm{n}$ ' period bond and a consequence of one - period bond.

Mathematically stated:

$\mathrm{Y}_{\mathrm{nt}}=\mathrm{E}_{\mathrm{t}}\left(\mathrm{Y}_{1},{ }_{\mathrm{t}} \mathrm{Y}_{1, \mathrm{t}+1} \mathrm{Y}_{1}, \mathrm{t}+2 \ldots . \mathrm{Y}_{1 \mathrm{t}+\mathrm{n}-1}\right)$

Simply put, current bond yields with different maturities reflect investors' expectations about future interest rates. For instance, given that low interest rates would result in economic recession, then an inverted interest rate structure would imply that future interest rate would be lower, thereby, predicting a recession. The expectation that recession could occur following low interest rate could be explained by the 'policy anticipation hypothesis'. It implies that any action of a short-term interest rate could make market participants to anticipate low rates since they had earlier expected recession. In this way, the financial markets' expectation of future policy is mirrored by the yield curve.

However, recent empirical evidence showed wide variation in the term premium over a span of time, suggesting the inadequacy of the expectation hypothesis alone to explain the yield curve dynamics (Joslin et al, 2014, Cohen et al, 2018).

Based on previous literature, this paper utilizes data on yield spread which is the difference between the $10-$ year government bond and the 3 - month treasury bill for Nigeria. According to Chinn and Kucko (2015), the mathematical relationship between the long term and short-term yield can be established as follows:

$i_{t}^{n}=\frac{\left(i_{t+i_{t=1+\cdots}^{e}+i_{t+n-1}^{e}}\right)}{n}+i_{t}^{n}$

Where $i_{t}^{n}$ is the interest rate on a bond of maturity $\mathrm{n}$ at time $\mathrm{t}, i^{e}$ is the expected interest rate on a one period bond for period $\mathrm{t}+\mathrm{j}$, based on information available at time $\mathrm{t}$, and $i_{t}^{n}$ is the liquidity (or term) premium for the n-period bond at time $t$.

Eq. 2 is based on the expectations hypothesis of the term structure which posits that a long-term bond yield equals the average of short term interest rates accrued over the life time of the long term bond.

Given that $i_{t}^{n}>0$ and it is expected to increase as n enlarges, the yield curve would slope upward as shortterm rates become constant over time. Consider an instance where $i_{t}^{n}=0$ implying that all variations in the longterm rates are explained by the expectations hypothesis if future short term rates are lower than the current short term rates leading to an inverted yield curve. Since low interest rates indicate economic slowdown, an inverted yield curve should therefore imply decreased economic activity. Chinn and Kucko (2015) provided two explanations why economic downturn is characterized by lower short term interest rates. First, economic slowdown reduces demand for credit by the private sector. At the same time, the ideal monetary policy response 
to economic slowdown would be to reduce the policy rate. Secondly, economic slowdown is in most cases precipitated by monetary policy stance.

\subsection{Empirical Literature}

There has been an extensive documentation of literature regarding the usefulness of the yield spread as a predictor of future economic growth. This paper compliments the increasing number of literature on the power of the yield curve to predict output growth. Some of the existing relevant empirical works in this area are discussed below.

The initial set of early empirical research work that investigated the relationship between yield spread and growth could be traced to the late 1980s. These were conducted primarily using the Unites States (US) financial data (Harvey, 1989; Stock and Watson, 1989; Nai-Fu chen, 1991; Estrella and Hardouvelis, 1991). Findings common to these studies suggested that an imminent or looming recession could be signaled by an inverted yield curve. Furlong (1989) in his paper acknowledged some predictive ability of the yield curve but expressed reservation about its reliability as a leading indicator.

The next group of related studies were conducted in the 1990s and 2000s with focus on countries outside the US. Among these were Davis and Henry (1994), Bonser-Neal and Morley (1997), Estrella and Mishkin (1997) and Estrella etal, (2003). Using the post-1970 data from non - US OECD countries, the authors' general conclusion was that future economic growth could be predicted using the yield spread to a relative extent. In a recent publication, Suart (2020) used monthly data covering 1974 to 2017 to test the potency of the slope of the term structure in predicting recessions in Switzerland. Results from the dynamic probit model suggested the usefulness of the term structure of interest rate in predicting recessions upto 19 months horizon. Most of these studies employed regression model to show the information content of the term structure of interest rate regarding future economic activity. The regression model used the term spread as a regressor while the gross domestic product (GDP) or index of industrial production (IIP) was adopted as the regressand.

In terms of comparison with other leading indicators, yield curve performance tends to be quite satisfactory with high predictive power. While the performance of other indicators like stock prices and interest rates were found to be fair, the yield spread outperformed them (Estrella, 2005). Studies by Dueker (1997), Dotsey (1998), Estrella and Mishkin (1998) and Berge (2015) also suggested the high performance of the yield curve over a large number of alternative leading indicators of future economic activity. Ergungor (2016) documented the existence of a negative relationship between the slope of a yield curve and the probability of a recession. In a related development, Naresh et al (2018), compared the relative effectiveness of the US yield spread over the Indian yield spread in the forecast of economic activities in India. Based on a strong correlation between the US long-term interest rate and its Indian counterpart, findings indicated that the US yield spread produced a better result in forecasting the Indian business cycle than the Indian yield spread.

A strand of the literature compared the ability of term premium with spread in predicting future economic activity. The term spread emerges from a decomposed spread into an expectations-based factor and a risk premium (Modena, 2007). Findings by Hamilton and Kim (2002) indicated that both components contained important information for predicting real economic growth. Their results along with those of Favero et al (2005) indicated that a reduction in the term premium could signal an impending recession. Similarly, Benzoni et al (2018) deployed the dynamic term structure model into two components of expectations and risk premia to show the connection between fluctuations in US treasury rates and future economic conditions. The paper found an association between monetary policy easing and an increase in in the likely occurrence of a recession within the next four quarters. Contrastingly, a decreased slope of risk premia was found to associate with the probability of either a higher or lower economic recession.

Contrastingly, Berk and van Bergeijk (2000) analysed the data from 12 euro area countries between 1970 and1998 and found that the term spread's informative ability to predict future output growth was limited. With regards to the period within which the yield spread could be reliably used to predict future growth, studies by Bonser-Neal and Morley (1997) as well as Chinn and Kucko (2015) suggested the ability of the spread to predict one year ( that is four quarters) ahead horizon. Another variant of the literature investigated the dynamic relationship between the yield curve and macroeconomic variables. In this category, Diebold et al (2006) used a VAR framework to show the influence of output growth and inflation on changes in yield curve and vice versa.

With respect to Nigeria, there are limited studies relating to the predictive ability of the yield curve in determining economic activities, perhaps due to paucity of data. One of the few related studies examined the information content of the yield spread in predicting future economic activities (Teriba, 2006). The author employed simple regression equations to investigate if the yield spread contains any useful information about the the level of future economic activity in Nigeria. The paper found the term structure spread useful in predicting real activity as measured by real GDP. However, the results showed stronger predictive power for future growth in domestic gross capital formation and real expenditure than for real GDP.

A similar work by Oyedele (2014) examined the relationship between the term structure of interest rate on the one hand, and economic activity and inflation, on the other hand. Using the Nigerian quarterly data series 
covering 1986 -2008 through the ordinary least square techniques, the paper found a positive and long run relationship with economic activity and inflation.

This paper seeks to enrich the existing literature and also provides value addition by employing most recent data series to investigate the predictive power of the yield curve to determine future economic perfromance in Nigeria. In addition, the paper attempted to test the potency of the yield curve in predicting the most recent $(2016 / 2017)$ economic recession in Nigeria.

\section{Methodology and data}

There are many ways of using the yield curve to predict future real activity. One common method uses inversions (when short term rates are higher than long term rates) as recession indicators. Obtaining predictions from the yield curve requires a lot of preliminary work. The key principle is to keep the process as simple as possible. A yield curve may be flat, up-sloping, down-sloping or humped. The standard solution uses a spread (difference between two rates). The usual challenge is to choose the spread between the right terms. The most used spread is between 10-year and 3-month bonds. In that case, the best solution is to use the yield curve, which shows the yield of each maturity. Creating and calculating the yield curve is a rather difficult task because there are many ways of computing it and countries adopt different models.

With regards to this study, the data for spreads were drawn from the CBN statistical bulletin. For the spreads, 10-year government bond rates minus 3-month treasury bill rates were chosen. Quarterly data were used for the spreads because the economic activity data were available on quarterly basis. As a measure of real growth, the index of industrial production sourced from the CBN database on a quarterly basis served as the proxy. The data period spanned 2007Q3 and 2019Q1. The time range covers the period of global financial crisis (2007-2009); preeconomic recession in Nigeria (2010-2015) and economic recession / slow recovery (2016-2019).

The basic model is designed to predict growth or decrease in economic activity for four quarters into the future based on the corresponding yield spread (Bonser-Neal and Morley, 1997). This was accomplished by conducting a series of regressions using the IIP and the spread between 10-year and 3-month bond. The following equation (1) was estimated for Nigeria:

$$
I I P_{t+n}=\alpha+\beta * \text { spread }_{t}+\varepsilon_{t}
$$

Where:

$I I P_{t+n}$ is the predictor of future real economic activity proxied by index of industrial production in time $t+n$

$n$ is the lag of spread,

spread $_{t}$ is the difference between 10-year and 3-month state bonds in time

$\varepsilon_{t}$ is a white noise

\section{Results and Discussions}

\subsection{Graphical Relationship between indicators of economic activity and yield spread}

First, we examined the graphical relationship between the variables of interest. Figure 1 shows the growth of real GDP and the lagged spread (4 quarters) between 10-year and 3-month bond yields; while Figure 2 showed the relationship between Index of Industrial Production (IIP) as a proxy for the level of economic activity and the lagged yield spread. Both graphs generally suggested that a decline in economic activity is preceded by a decrease in the yield spread and narrowing yield spread often signals a decrease in the level of economic growth.

Though, a generally positive relationship between economic activity and yield spread can be observed from the two graphs, Figure 2 showed a rather better correlation between the two variables, hence our adoption of the Index of Industrial Production as the proxy of economic activity in subsequent analysis. 


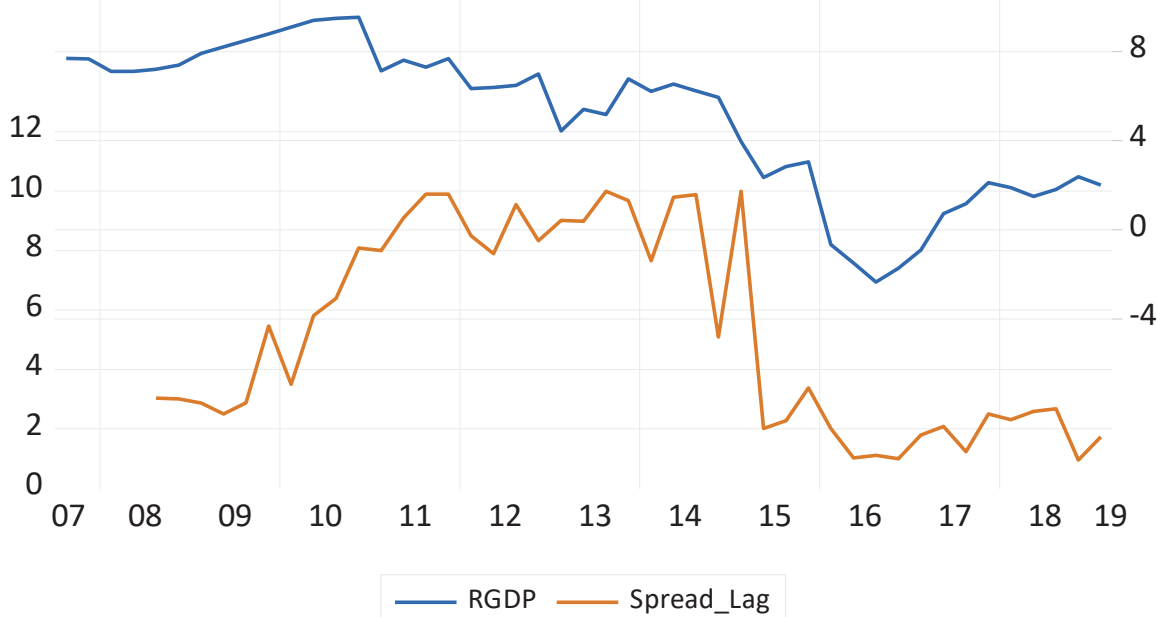

Fig. 1: Yield Spread and Real GDP movement

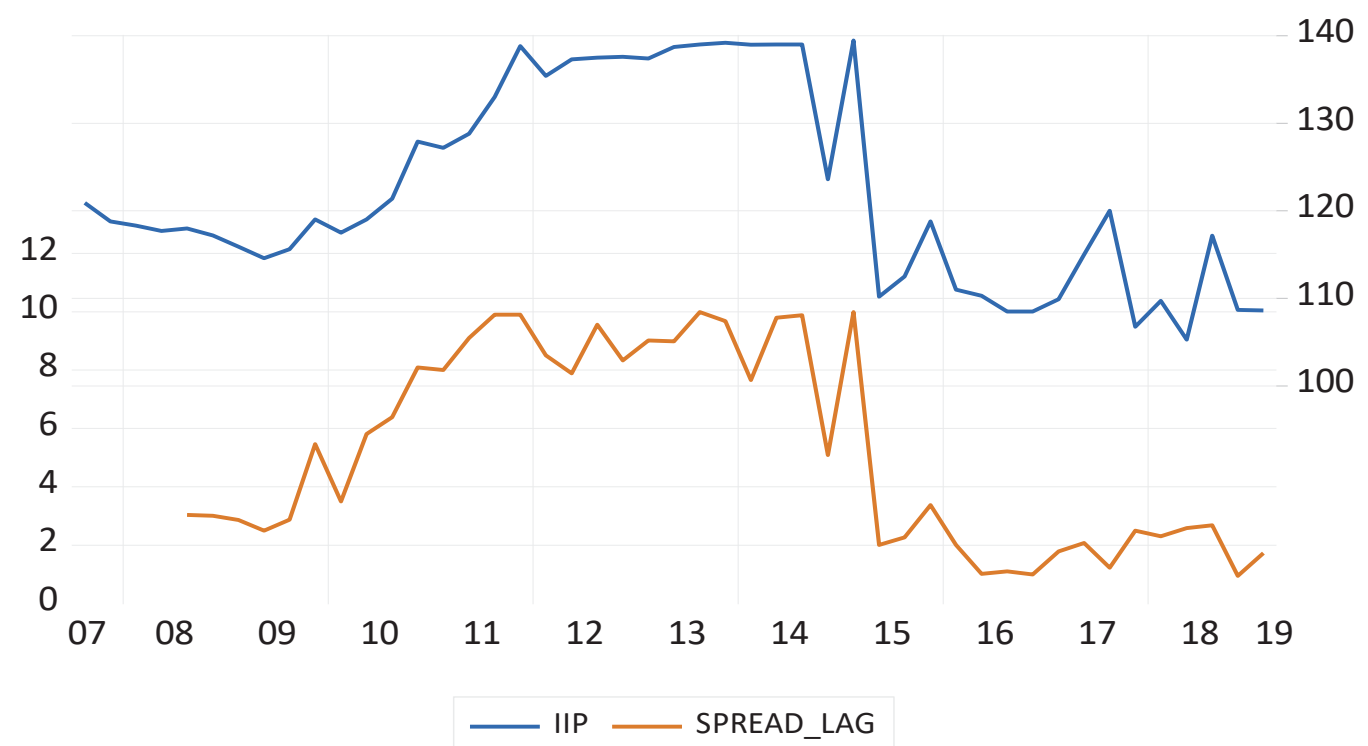

Fig 2: Yield Spread and Index of Industrial Production movements

The level of dependency between IIP and lagged spread is clearly more visible in 2015 prior to the recession that started in 2016. Thus, the recession in 2016-2017 was preceded by several quarters of decreasing spread. The same behavior was observed in 2007-2008 during the global financial crisis.

\subsection{Regression Analysis}

To investigate whether the yield curve accurately predict future economic activity, we generated regression results for the various data samples. We used the whole sample data series and also divided the sample data along major economic developments periods in the country. These include the era of the global financial crisis- GFC (20072009); pre-economic recession in Nigeria (2010-2015) and economic recession / slow recovery (2016-2019).

\subsubsection{Regression Results for the Whole Sample (2007-2019)}

The whole sample data series include the Index of Industrial Production (IIP) data between 2007Q3 and 2019 Q1. Table 1 showed the regression results for the entire sample data. The result indicated a low $\mathrm{R}^{2}$ of $21 \%$ and a statistically significant model.

Table 1. Results of Whole Sample data using the OLS Regression

\begin{tabular}{|c|c|c|c|c|}
\hline Whole sample & Constant & Spread & P-Value $\mathrm{R}^{2}$ & \\
\hline 2007Q3-2019Q1 & $130.949-2.600$ & & $0.001 * * *$ & 0.207 \\
\hline
\end{tabular}

$* * *$ denotes significance at $1 \%$ 
This suggests that the model though, statistically significant, could not be largely relied upon for predicting future economic activities due to its low $\mathrm{R}^{2}$. The weak performance of the model could be attributed to the different economic developments that traversed the period especially the 2007-2009 GFC and the 2016-2017 economic recessions in Nigeria.

\subsubsection{Regression Results for the GFC Era (2007-2009)}

One of the divided sample data sets covered the period of the GFC (2007-2009). The results as contained in table 2 showed a statistically significant model at $1 \%$ with a high $\mathrm{R}^{2}$ of $57.5 \%$.

Table 2. Results of OLS Regression during the GFC period

\begin{tabular}{lrl}
\hline GFC period & Constant & Spread P-Value $\mathrm{R}^{2}$ \\
\hline 2007Q3-2009Q4 & $120.363-0.573$ & $0.011 * * 0.575$ \\
\hline
\end{tabular}

** denotes significance at 5\%

This implied that about $57.5 \%$ of the variation in economic activity could be explained by the change in bond spread. The model would therefore be considered as a reliable predictor of future economic activity. This means that the future economic activity of Nigeria could be predicted by the following equation.

$\mathrm{IIP}_{\text {Nigeria }}=120.3631-0.573255^{*}$ Spread $_{\text {Nigeria } t,} \quad \mathrm{R}^{2}=0.575$

5.2.3 Regression Results for Nigeria's recent Pre-Recession Period (2010-2015)

Regression analysis was carried out for the period prior to the 2016/2017 Nigeria's economic recession. The data set covered 2010 to 2015 during which several developments built up in the economic system and eventually plunged the economy into recession in the first quarter of 2016.

Results of the analysis as shown in table 3 indicated statistical significance at $1 \%$ with a high $\mathrm{R}^{2}$ of $54.7 \%$.

Table 3. Results of OLS Regression during the pre-recession period

\begin{tabular}{llll}
\hline Pre-recession & Constant & Spread & P-Value R \\
& & \\
\hline 2010 Q1-2015Q4 & $142.194-4.298$ & $0.000 * * *$ & 0.547 \\
\hline
\end{tabular}

*** denotes significance at $1 \%$

With almost $55 \%$ of the variation in industrial production being explained by the model, it suggests that the model could also be employed for predicting future economic activity in Nigeria. The regression equation for predicting future economic activity could be represented as follows:

$\mathrm{IIP}_{\text {Nigeria }}=142.1939-4.298108 *$ Spread $_{\text {Nigeria }}, \quad \quad \mathrm{R}^{2}=0.547$

The high $\mathrm{R}^{2}$ produced by this model could be indicative of the influence of the key factors that triggered the economic recession. Some of these factors include geopolitical and trade tensions which heightened, beginning from 2014 with its attendant effects on global trade and capital flows. The significant decline (about $60 \%$ ) in crude oil prices between 2014 and 2016 led to a sharp drop in government revenue and spending while the United States monetary policy normalization resulted in huge capital reversals in emerging and developing economies, including Nigeria. The combination of these shocks including other domestic factors triggered economic recession in the first quarter of 2016.

5.2.4 Regression Results During Economic Recession and Post-Recession Era (2016-2019)

Results of the analysis between 2016 and 2019 are displayed on table 4 below.

Table 4. Results of OLS Regression during the recession/post-recession period

\begin{tabular}{|c|c|c|c|}
\hline Recession/post & Constant & Spread P-Value $\mathrm{R}^{2}$ & \\
\hline 2016Q1-2019Q1 & 109.5090 .374 & 0.620 & 0.023 \\
\hline
\end{tabular}

The model was statistically insignificant with very low $\mathrm{R}^{2}$ value of $2.3 \%$ indicating that it cannot be deployed to predict future economic activities in Nigeria.

\section{3. Predicted Values of Index of Industrial Production between $2019 Q 2$ and $2020 Q 1$}

Having established a reliable model for predicting future economic activity, we proceeded to compute the future Index of Industrial Production for the next four quarters. To compute the IIP, we employed the automatic ARIMA forecasting method and generated the Spread values for 2019Q2 to 2020Q1. The computed IIP values for 2019Q2, 2019Q3, 2019Q4, and 2020Q1 are presented in table 5. 
Table 5. Predicted Values for the Index of Industrial Production in Nigeria

\begin{tabular}{llc}
\hline Quarter & Spread & IIP \\
\hline 2019 Q2 & 3.20 & 118.53 \\
2019 Q3 & 2.58 & 118.88 \\
2019 Q4 & 2.49 & 118.94 \\
2020 Q1 & 2.59 & 118.88 \\
\hline
\end{tabular}

The results suggest that economic activity as measured by IIP would improve up to 118.88 in 2019Q3, peak at 118.94 in 2019Q4 and drop slightly to 118.88 in 2020Q1

\section{Conclusion}

The study examined the capability of the yield curve to accurately predict the level of economic activity. It was found that the 10-year less 3-month bond spread has substantial predictive power and should provide good forecast of the level of economic activity up to four quarters into the future. We showed that the best predictive lags of spreads are lags of four quarters in order to get the best results for predictive models. The results presented above confirm that 10-year and 3-month bond yield spread has a significant predictive power for economic activity. Further analysis showed the change of behavior of the models before, during and after the 2016/2017 economic recession. For instance, dividing the sample into developmental periods made a difference between pre-recession and post-recession periods. It also strongly demonstrated the influence of Spreads on predicting the future level of economic activity.

\section{References}

Berge T. J. (2015), "Predicting recessions with leading indicators: model averaging and selection over the business cycle", Journal of Forecasting, 34, 455-471.

Berk, J.M., \& Van Bergeijk, P. (2000). Is the yield curve a useful information variable for the Eurosystem. European Central Bank. Working paper No. 11.

Bernard, H., \& Gerlach, G. (1996). Does the Term Structure Predict Recessions? The international evidence. Bank for International Settlements, Working paper no. 37, September.

Bonser-Neal, C., and T. R. Morley. (1997). "Does the Yield Spread Predict Real Economic Activity? A Multicountry Analysis”, Federal Reserve Bank of Kansas City, Economic Review, Third Quarter.

Campbell, R H (1988): "The real term structure and consumption growth", Journal of Financial Economics, 22, pp 305-33.

Chinn, M. \& Kucko, K. (2015). The Predictive Power of the Yield Curve Across Countries and Time. International Finance 18 (2): 129-54.

Cohen B. H., P. Hördahl and D. Xia (2018), “Term premia : models and some stylised facts”, BIS Quarterly Review, September.

Cuaresma J.C., Gnan E. \& Ritzberger-Grünwald D. 2005. The term structure as a predictor of real activity and inflation in the euro area: a reassessment. Review of World Economics 141(2): 318-342.

Davis, E.P and S.G.B. Henry (1994).The Use of Financial Spreads as Indicator Variables: Evidence for the United Kingdom and Germany. IMF Staff Papers 41: 517-525.

Davis, E.P., \& Fagan, G. (1997). Are financial spreads useful indicators of future inflation and output growth in E.U countries. Journal of Applied Econometrics, 12, 701-714.

Diebold, F.X., Rudebusch, G.D., Aruoba, S.B., (2006). The macroeconomy and the yield curve: A dynamic latent factor approach. Journal of Econometrics 131, 309-338.

Dotsey, M. (1998). The predictive content of the interest rate term spread for future economic growth. Federal Reserve Bank of Richmond Economic Quarterly, Vol. 84(3), 31-51.

Drakos, K. (2001). Monetary policy and the yield curve in an emerging market: The Greek case. Emerging Markets Review, 2, 244-262.

Duarte, A., Venetis, J.A. and I. Payá (2004). Predicting Real Growth and the Probability of Recession in the Euro Area Using the Yield Spread. IVIE working papers AD 2004-31.

Dueker, M.J. (1997). Strengthening the case for the Yield Curve as a Predictor of US Recession. Federal Reserve Bank of St. Louis Review 79: 41-45.

Ergungor, O. E. (2016), "Recession Probabilities," Federal Reserve Bank of Cleveland Economic Commentary, August 23, 2016. 
Estrella, A. (2005). The yield Curve as a Leading Indicator: Frequently Asked Questions. Downloaded from the internet on

$15 / 12 / 2017$ https://cfainstitute.org/learning/products/publications/contributed/Pages/the_yield_curve_as_a_leading_indi cator_frequently_asked_questions.aspx.

Estrella, A., and Hardouvelis, G. (1991). The Term Structure as a Predictor of Real Economic Activity, Journal of Finance, 46, (2), 555-576.

Estrella, A. and F. S. Mishkin. (1995). "The Term Structure of Interest Rates and its Role in Monetary Policy for the European Central Bank," NBER Working Paper 5279, September.

Estrella, A., \& Mishkin, F. S. (1998). Predicting US Recessions: Financial Variables as Leading Indicators. The Review of Economics and Statistics, 80, 45-61.

Estrella, A., \&Mishkin, F. S. (1996) “The Yield Curve as a Predictor of U.S. Recessions,” Federal Reserve Bank of New York Current Issues in Economics and Finance, June, 2(7).

Estrella, A., \&Mishkin, F. S. (1997). The predictive power of the term structure of interest rates in Europe and the United States: Implications for the European Central Bank. European Economic Review, 41, 1375-1401.

Estrella, A., Rodrigues, A.P., \& Schich, S. (2003). How Stable Is the Predictive Power of the Yield Curve? Evidence from Germany and the United States. Mimeo, Federal Reserve Bank of New York.

Favero C.A., Kaminska I., Soderstrom U., 2005, The Predictive Power of the Yield Spread: Further Evidence and a Structural Interpretation, CEPR Discussion Paper.

Hamilton J.D., Kim D.H., 2002, A Re-examination of the Predictability of Economic Activity Using the Yield Spread, Journal of Money, Credit, and Banking, Vol. 34, 340 - 360.

Haubrich, J.G., and A.M. Dombrosky. (1996) "Predicting Real Growth Using the Yield Curve," Federal Reserve Bank of Cleveland Economic Review, vol. 32 (First Quarter), pp. 26-34

Furlong, F.T. (1989). The Yield Curve and Recession. Federal Reserve Bank of San Francisco. Weekly Letter, March 10

Harvey, C. R. 1989. "Forecasts of Economic Growth from the Bond and Stock Markets," Financial Analyst Journal 45(5), pp. 38-45.

Haubrich, J., \& Dombrosky, A. (1996). Predicting real growth using the yield curve. Federal Reserve Bank of Cleveland Economic Review, 32, 1st Quarter, pp.26-34.

Hvozdenska, J. (2015) The Application of Sovereign bond Spreads: The case of United Kingdom, Iceland, Norway, Switzerland and Russia. Proceedings of the 2nd Global Conference on Business, Economics, Management and Tourism, 30-31 October 2014, Prague, Czech Republic.

Joslin S., M. Priebsch and K. J. Singleton (2014), "Risk premiums in dynamic term structure models with unspanned macro risks", The Journal of Finance, 69(3), 1197-1233.

Modena, M (2007). The Term Structure and the Expectations Hypothesis: a Threshold Model. Available online on https://mpra.ub.uni-muenchen.de/9611/.

Mohapi,T.A. and I. Botha (2013) The Explanatory Power Of The Yield Curve In Predicting Recessions In South Africa. International Business \& Economics Research Journal - June 2013 Volume 12, Number 6.

Nai Fu Chen (1991). Financial Investment Opportunities and the Macroeconomy. Journal of Finance, 46(2):529554

Oyedele, O. (2014). The relationship between the term structure of interest rates and Nigeria economic growth and inflation rate. International Journal of Innovation and Scientific Research, 11(2): 295-303.

Stock, J.H., \& Watson, M.W. (1989). New Indices of Coincident and Leading Indicators, In O. Blanchard and S. Fisher edited NBER Macroeconomic Annual. Cambridge, MIT Press.

Teriba, A (2006). Informative content of Interest Rates Spread in Nigeria, Economic Associates.

Turnovsky, S. J. (1989). The term structure of interest rates and the effects of Macroeconomic Policy. Journal of Money, Credit and Banking, 21, (3), 321-347. 